\title{
Ledelse af fællesskabelse
}

\author{
Af Marie Aakjoer \& Eva Pallesen *)
}

\begin{abstract}
Resumé
Velfærdsproblemer adresseres i stigende grad på tværs af sektorer ud fra ideen om, at nye løsninger skal samskabes i fællesskab med de mennesker, hvis liv de berører og gennem aktivering af eksisterende ressourcer i civilsamfundet. I artiklen undersøger forfatterne, hvordan et lokalt fællesskab konstitueres med afsæt i en case, hvor en gruppe borgere og en offentlig koordinator afprøver en digital platform som en måde at understøtte borgernes fællesskab. Analysen tager afsæt i social praksisteori og en relationel ontologi for derved flytte fokus til en procesorienteret forståelse af fællesskabelse, i hvilken det 'fælles' kan ses som et fænomen, der kontinuerligt skabes og genskabes. Analysen peger på fælleskabelse som en proces, der konstitueres gennem sammenfletningen af handlinger, erfaringer og forestillinger i interaktion med spatiale, temporale og materielle elementer. Artiklen slutter med en diskussion af artiklens pointer i relation til offentlige aktører.
\end{abstract}

Emneord: Fællesskabelse, samskabelse, velfærd, social innovation, ledelse

*) Marie Aakjær er lektor, ph.d. og Eva Pallesen er docent, ph.d. Begge er ansat på Center for Ledelse og Oplevelsesdesign på Professionshøjskolen Absalon. 


\section{A. Baggrund og problemfokus}

\section{Nye koblinger mellem samskabelse og social innovation: fællesskabelse}

Denne artikel sætter fokus på hvordan fællesskabelse konstitueres som social praksis. Vi argumenterer for at fællesskabelse i disse år træder frem som et nyt begreb i en offentlig ledelseskontekst, og får en ny centralitet i bestræbelser på at udvikle velfærd gennem samskabelse og social innovation. Imidlertid er fællesskab som fænomen underbelyst i samskabelses- og innovationslitteraturen på trods af at begge felter beskæftiger sig med kollektive (borger-)kræfter som middel og mål til offentlig velfærdsskabelse og -innovation. Artiklens bidrag retter sig således mod dette uudfyldte rum i litteraturen.

Potentialet i borgerkræfter er for alvor kommet i den offentlige sektors søgelys i forlængelse af pres på offentlige budgetter og øgede krav om effektivitet og kvalitet. Offentlige organisationer søger disse år nye svar på, hvilke aktører og ressourcer der kan deltage eller mobiliseres i bestræbelserne på at opretholde og skabe velfærd (Hartley et al., 2013; Sørensen \& Torfing, 2018). I denne kontekst har begreber som social innovation, samskabelse og samproduktion fået stigende opmærksomhed både teoretisk og empirisk. Ifølge Sabato, Vanhercke \& Verschraegen (2017) er social innovation de seneste 10 år vokset frem og har fået en central position i EU's agenda, og begrebet bliver i EUdokumenter præsenteret som centralt i forhold til at forny velfærdsstaten og legitimere specifikke politiske mål. I praksis såvel som i forskning på feltet anvendes social innovation og samskabelse ofte sidestillet (Agger \& Tortzen, 2015; Agger, Tortzen, \& Rosenberg, 2018). I en dansk kontekst har samskabelse været koblet til den offentlige sektors udviklingstænkning på forskellige måder: Én tilgang til samskabelse vægter borgerinddragelse i beslutningsprocesser og udvikling af services ud fra argumentet om, at borgeres ideer og perspektiver må inddrages, for at nye og bedre løsninger kan identificeres (se fx Sørensen \& Torfing, 2018) eller for at den demokratiske værdi øges (Tortzen, 2019). En anden kobling af samskabelse og velfærdsudvikling fokuserer på, at den enkelte borgers medvirken er afgørende for, at centrale offentlige indsatser lykkes, hvilket fx gælder indsatser såsom rehabilitering og telemedicin (Ulrich, 2018). Disse eksempler dækker over forskellige betydninger af samskabelse og vægtning af værdiskabelse (innovation/kvalitet, demokrati/deltagelse og effektivitet/kvalitet), men har det til fælles at de grundlæggende tager udgangspunkt i en velfærdsservice, der leveres af det offentlige.

De senere år ses imidlertid nye typer af initiativer med relation til samskabelse og social innovation, skyde frem. INSP, SYMB og Sager der Samleri er eksempler på initiativer, som er kendetegnet ved at være nye former for borger-til-borger initiativer i grænselandet - eller mellemrummet - mellem civilsektor og offentlig sektor (Digmann, Nielsen, \& Ejlersen, 2018). Disse initiativer adskiller sig fra den samskabelse, som initieres af offentlige organisationer ved sit fokus på at skabe rammer for borgerfællesskaber, som kan noget andet end det offentlige kan alene, og hvis værdi tælles på andre 
bundlinjer. Sådanne initiativer er indlejret i aktuelle diskurser om samskabelse og samproduktion som midler til at finde løsninger på presserende sociale udfordringer, men indebærer at spørgsmålet om foellesskabers tilblivelse får en ny central placering.

En udviklingstendens, der spiller ind i dette fornyede fokus på fællesskaber, er tilkomsten af nye typer informations- og kommunikationsteknologier (ICT), der muliggør at nye konstellationer af aktører samarbejder og interagerer på nye måder. En vifte af digitale platforme for social interaktion foreslås således p.t. fra iværksættere og teknologiudviklere som de nye lokale mødesteder eller 'opslagstavler' (fx når den lokale Brugs er lukket eller som supplement til den analoge opslagstavle i den eksisterende Brugs), hvor borgere kan mødes, tale sammen eller hente information. Ideen bag borger-til-borger portalerne er at mobilisere relationer for at skabe sociale fællesskaber på kryds og tværs i kommunerne og at danne rammerne for eksempelvis et sundhedsfællesskab. Platformene tænkes som nye berøringspunkter og forbindelser mellem borgere, som fx søger efter en gå-, løbe-, eller træningsmakker, en spiller til fodboldholdet, eller en hjælpende hånd. Men potentialet kan også være mere vidtgående og adressere 'nogle at tale med om angst, depression og lign', venskab, og ny familie ('bonusbedsteforældre eller bonusbørnebørn').

Follesskaber rykker således ind som centralt i forhold til velfærdsudvikling, og får en fornyet betydning i forhold til aktivering af teknologi (Melander, 2018), social innovation og samskabelse. Borgeren i centrum bliver snarere til borgerne i centrum - det individuelle udgangspunkt bliver utilstrækkeligt og fællesskabet kommer til syne som genstand for offentlig ledelse og styring. Dette kalder imidlertid på en dybere forståelse af hvordan det fælles skabes eller opstår: Hvordan konstitueres fællesskabelse og hvilke elementer er af betydning for fællesskabers opståen, kontinuitet og udvikling? Hvilke handlinger består fællesskabelsen gennem?

Artiklen adresserer disse spørgsmål med afsæt i en empirisk case, hvor et netværk af ældre borgere sammen med en kommunal koordinator forsøger at styrke de ældres fællesskab og i den sammenhæng afprøver en digital platform. I casen optræder teknologien som et instrument, der er tiltænkt i sig selv at muliggøre værdiskabelse og effekter som sundhed og velvære via borger-tilborger-fællesskabet. I artiklen går vi bag om denne idé, og undersøger selve fællesskabelsen som en bevægelse i en lokal, social praksis. Analysen anlægger et relationelt og transaktivt blik (Simpson 2009), som forskyder fokus fra individ og afgrænsede redskaber som teknologi, til relationer og transaktionen mellem aktører, ting, steder og tid og til den gensidige proces, hvor igennem fællesskabelse tillægges mening og betydning. Med baggrund i analysen, foreslår vi at fælleskabelse kan forstås igennem tre kontingente dimensioner: en handlingsdimension, erfaringsdimension og forestillingsdimension - samt fremhæver betydningen af den spatielle, temporale og materielle kontekst for fællesskabelsen. Artiklen pointerer her, at fællesskabelse opstår i en dynamik mellem det faste og stabiliserende (fx fastlagte roller, rum og tidsrum) og det åbne og fleksible (fx drømme, 
håb, åbne samværsformer). I denne kontekst kan offentlige aktører spille en vigtig rolle i forhold til at være med til at sikre de stabliserende elementer, men må samtidig følge og spille ind i fællesskabelsens egne dynamikker uden en mulighed for entydigt at styre dem mod bestemte resultater inden for bestemte tidshorisonter.

\section{Oversigt over artiklen}

Inden vi tager fat på analysen, introducerer vi artiklens teoretiske grundlag med afsæt i en relationel procesontologi (afsnit B). I afsnit C præsenterer vi artiklens empiriske case samt det metodiske grundlag for analysen. Herefter følger analysen (afsnit D) struktureret efter de dimensioner der er nævnt ovenfor. I afsnit E følger en diskussion af de implikationer ambitionen om fællesskabelse aktualiserer for offentlige aktører. Afsnit F konkluderer og perspektiverer artiklens pointer.

\section{B. Teoretisk ramme: Et relationelt og transaktivt blik på fællesskab}

Selvom forskningslitteraturen indenfor samskabelse og social innovation beskæftiger sig med kollektive (borger-)kræfter som middel og mål til offentlig velfærdsskabelse og -innovation, er selve spørgsmålet om fællesskabelse i en velfærdskontekst ikke selvstændigt tematiseret i disse felter. Artiklen bidrager til dette uudfyldte rum i litteraturen ved at undersøge fællesskabelse i en velfærdskontekst som en lokal, social praksis. Den teoretiske ramme for analysen tager afsæt i en relationel, transaktiv ontologi (Simpson, 2009) som indgang til at undersøge, hvordan fællesskabelse opstår og består. Det teoretiske afsæt har således rødder i amerikansk pragmatisme og praksisteori, men relaterer sig også til en aktuel drejning i organisationsteorien i retning af procesontologisk udgangspunkt (Hernes, 2017).

Den case, vi tager afsæt i her, sigter i udgangspunktet mod at skabe den type samskabte løsninger af velfærdsopgaver, som kan beskrives som social innovation, hvor det sociale udgøres af såvel processen som målet og værdien (means and outcomes) (BEPA, 2011). En definition af social innovation, der rummer dette perspektiv på det sociale som omdrejningspunkt, definerer social innovation som:

new approaches to meeting social needs which are both social in their means and in their ends, and which engage and mobilise the beneficiaries and help to transform social relations by improving beneficiaries' access to power and resources.

(Millard \& Carpenter, 2014, s. 4)

Det sociale i social innovation angår således både den måde innovation opstår på; nemlig nye sociale relationer og samarbejdsflader, og den mulige effekt; dvs. øget kapacitet og nye løsninger (eller 
forbedret håndtering) af sociale problemer. I en velfærdskontekst foregår social innovation på særlige betingelser, eftersom relationen mellem borger og professionelle er direkte, innovationsprocessen og spredningen af innovation er fortløbende, og skabelse og spredning af innovation finder sted i komplekse samspil mellem systemer, logikker og kontekster (Crepaldi, De Rosa, \& Pesce 2012). Dette betyder, at mål for sociale innovationer i velfærdskontekster ofte er flertydige og overlappende, og at midlerne hertil går gennem forandringer i roller og relationer som i nærværende case: gennem borgerfællesskaber. Men hvad sker der med forholdet mellem middel og mål, når innovation af velfærd bliver samskabt og social?

Som i eksemplet med telemedicinsk behandling af KOL-patienter, forandres ikke alene organisering af og standarder for praksis, og det, der produceres og ledes frem mod (sundhed), men også relationer mellem aktører (fx mellem sygeplejersker og læger, eller mellem sygeplejersker og borgere) (Nickelsen \& Elkjaer, 2017). I casen, som denne artikel tager afsæt i, ser vi desuden et sammenfald mellem middel og mål: fællesskabelsen er midlet til at opnå mål om øget velfærd, trivsel og sundhed. Men trivsel og sundhed er tilstande der eksisterer over tid, og som mål kan de ikke håndteres en gang for alle eller som afgrænsede eller afsluttede mål. Opretholdelsen af fællesskabelsen som en fortløbende bevægelse bliver da et mål i sig selv. Social innovation og samskabelse resulterer dermed ikke kun i nye, målbare produkter, services eller processer, men inkluderer forandringer i samarbejdsformer og konstellationer mellem mennesker, teknologi og tid.

Ligeledes må den værdi, innovationen skaber, beskrives og begribes med andre og nye begreber. Fra litteraturen på samskabelsesområdet argumenterer Ulrich (2018) for, at værdiskabelse kan ske på tre bundlinjer: en økonomisk (fx mere for mindre), en kvalitativ (bedre kvalitet eller innovation) og demokratisk (større indflydelse). På baggrund af et review af samskabelseslitteraturen ser Agger, Tortzen og Rosenberg (2018) tre tilsvarende former for værdiskabelse og lægger offentlig værdi (public value, jf. (Moore, 1995)) til som en fjerde bundlinje. Offentlig værdi beskrives som et sammensat paraplybegreb, der dækker over sociale, kulturelle og miljømæssige dimensioner af værdi (Agger Tortzen og Rosenberg 2018), herunder social kapital og tillid. Offentlig værdi er med andre ord en bred betegnelse for værdiskabelse, der delvist inkluderer og overskrider de fire første bundlinjer. Vi ser, at fællesskabelse er beslægtet med de former for offentlig værdi, der beskrives i litteraturen, men behandles ikke som selvstændigt fænomen, ligesom det forbliver underforstået hvordan fællesskabelse kan placeres og relateres til de fire bundlinjer.

Initiativerne rettet mod samskabelse og innovation af velfærd involverer i større eller mindre omfang det offentlige, se fx (Sørensen \& Torfing, 2018; Ulrich, 2018), men en række grundlæggende, kendte størrelser - fx målgruppebegrebet, målfastsættelse eller lineære forbindelser som indsats og resultat, ydelse og modtager - er ikke længere entydige. På trods af at forskningsfelter omkring innovation og samskabelse beskæftiger sig med kollektive (borger) kræfter som middel og mål til 
offentlig velfærdsskabelse og -innovation og med konsekvenserne af dette for hvordan innovation opstår (herunder roller og relationer, er fællesskabelse og hvad der konstituerer fællesskabelse således ikke selvstændigt belyst i disse felter.

Når fællesskabelse træder frem som middel og mål handler det ikke alene om borgeres deltagelse og ressourcer i forhold til at skabe innovation inden for rammerne af en service, det offentlige definerer og leverer, heller ikke alene om, at rollerne ændrer sig (som i fx rehabilitering), men også om at selve det, som det ønskede resultatet er og kan være, transformeres. Med fællesskabelse som middel og mål må vi medregne tid, rum og levet liv som aspekter af den velfærd, der samskabes. Det er selve horisonten for, hvad det er for en værdi vi gerne vil skabe, der transformeres eller overskrides.

For at undersøge, hvordan fællesskabelse konstitueres som en bevægelse over tid, anlægger vi et relationelt, perspektiv. Med dette blik forskydes fokus fra afgrænsede enheder som individer/aktører, steder, ting og teknologi, til relationer og transaktionen (Dewey \& Bentley, 1949 [1991]) mellem aktører, ting, steder og tid og til den gensidige bevægelse hvor igennem transaktionerne får mening og betydning. I artiklen undersøger vi dermed fællesskabelse som:

"a transactional social process involving experience and action as mutually informing aspects of human conduct."

(Simpson 2009, p. 1329)

Et relationelt, procesontologisk blik dirigerer således opmærksomheden til handlinger og deltagelse i sociale situationer, og til en sensitivitet over for hvordan aktører kontinuerligt og over tid skaber (opretholder og forandrer) en social praksis samtidig med at aktørernes identitet skabes og genskabes. Aktører og (sociale) situationer betragtes således som situerede og gensidigt konstituerende. I dette perspektiv anses alle aktører som deltagere i og medskabere af en mængde forskellige sociale verdener og praksisser (Simpson, 2009), hvad enten disse drejer sig om at være medarbejder i et aktivitetscenter for ældre borgere, tennisspiller, far/mor, KOL-patient, studerende på sygeplejerskestudiet, eller andet. Gennem deltagelse i en given social praksis udtrykker aktører, at de mestrer den viden og de normer og konventioner, der værdsættes i den givne praksis. Derigennem gør de sig genkendelige som deltagere, medlemmer og medskabere, der 'ved', 'kan' og 'hører til' den sociale verden. Deltagelse er en grundlæggende betingelse for oplevelsen af og den aktive skabelse af, 'hvem vi er', fordi tilhørsforhold skabes og bekræftes gennem deltagelse. Det er gennem handlinger (ageren) i sociale praksisser og gennem den måde, andre oplever disse handlinger på, at identitet og oplevelse af at 'være nogen' skabes. Oplevelse af at være 'sig selv' skabes og genskabes kontinuerligt gennem episoder af kontinuitet og diskontinuitet, og kan illustreres gennem konstruktionen af fortællinger om sammenbrud og kontinuitet (Weick, 2001). 
Med andre ord er fællesskaber en fundamental del af livet og samfundet, der betinger menneskers handlemåder og oplevelse af livet, af velbefindende, mestring, ensomhed, mv.

Dette teoretiske afsæt åbner således for at undersøge fællesskabelse som en kontinuerlig tilblivelsesproces, der opstår gennem handling og oplevelse/erfaring, 'punktueret af begivenheder, der fremdrager den socialt konstruerede forståelse ud af tidens kontinuerlige flux' (Elkjaer \& Simpson, 2011, vores oversættelse). I det følgende vender vi os nu med den empiriske case samt de metodologiske implikationer af det teoretiske afsæt i en relationel, processuel ontologi.

\section{Den empiriske case: Lungenetværket som fællesskab}

\section{Casepræsentation}

Artiklens empiriske grundlag er et forsknings- og udviklingsprojekt, der som et delprojekt af MATURE-projektet ${ }^{\text {ii }}$ undersøger, hvordan udveksling af omsorg og tjenester i fællesskaber af ældre borgere kan understøttes via en digital platform (herefter LM platformen), med sigte på at højne kvaliteten i det levede liv: dvs. deltagernes oplevelse af velbefindende og af deres oplevelse af kapacitet og evner til at udøve kontrol over eget liv. Forskningsprojektet er således indlejret i den offentlige og politiske diskurs om social innovation og den stigende opmærksomhed på samskabelse og samproduktion som midler til at finde løsninger på presserende sociale udfordringer relateret til ressourceknaphed, sundheds- og demografiske ubalancer, etc. (Murray, Caulier-grice, \& Mulgan, 2010).

Selvom casen ikke fokuserer direkte på funktionel evne og rehabilitering, afspejles tankegangen om hverdagsrehabilitering alligevel i den indbyggede ambition om at opretholde sociale og funktionelle evner hos målgruppen af ældre borgere. Ved at støtte de ældres sociale netværk er forventningen, at de vil holde sig sundere, gladere og derved i højere grad holde sig fri af offentlige services, fx kontakt til sundhedspersonale eller hospitalsindlæggelser. Teknologien - en digital platform - er i projektideen tænkt som en muliggørende faktor i dette. Deltagerne i casen er borgere, som mødes i hvad de kalder Lungenetværket; et netværk for borgere med nedsat lungefunktion (bl.a. KOL). Netværket støttes til daglig af en kommunalt ansat koordinator, som tager sig af planlægning, afvikling og kommunikation af en ugentlig træningsaktivitet og et månedligt socialt arrangement. Mens delprojektets tiltag med anvendelse af platformen stod på, spillede koordinator en central rolle i forhold til at lægge indhold på platformen og hjælpe deltagere i netværket med at bruge platformen. Platformen blev aldrig en succes for Lungenetværket og brugen af platformen var sporadisk, fordelt på et fåtal af deltagere. Der kan peges på flere årsager til dette, bl.a. tekniske fejl i platformen og platformens generelle brugervenlighed, barrierer i form af kompetence-gab og 
holdninger til ICT mere generelt, der medformede den meningsskabelse om platformen, som fandt sted i netværket.

\section{Metodisk tilgang}

Det teoretiske afsæt i relationel procesontologi og praksisteori, og den deraf følgende ambition om at studere fællesskab som noget der hele tiden bliver til i det levede hverdagsliv (fællesskabelse) snarere end som en fast eller formelt funderet størrelse, rejser en metodisk fordring: hvordan kan man studere fællesskabet som tilblivelse? Snarere end at definere fællesskab på forhånd og omsætte det til en række kriterier som vi kigger efter med henblik på at konstatere om det findes eller ej, tager vi her et fænomenologisk afsæt. Det vil sige, at vi udforsker hvad et fællesskab i praksis viser sig at være i den studerede kontekst, når vi ser på hvad der holder interaktionen mellem borgerne (der netop ikke er en formelt etableret gruppe) sammen.

Dette afsæt i fællesskab/fællesskabelse som noget der er erfaret og levet, snarere end noget der kan foruddefineres som summen af generaliserede enkeltfaktorer, peger på dataindsamlings- og analysemetoder, der er egnede til at indfange erfaringer som dynamiske helheder og som har fokus på at forstå fænomener i kontekst. Dette har ledt os til dataindsamlingsmetoder, der overordnet kan knyttes til en etnografisk tilgang. Det etnografiske studie er traditionelt en forskningstilgang hvor forskeren lever med og som dem han studerer med henblik på at erfare, forstå og beskrive sociale fænomener. I vores kontekst, har inspirationen fra en etnografisk tilgang især handlet om, at denne lægger vægt på at skildre "det levede liv" i sin komplekse og dynamiske helhed, sådan som det opstår i interaktionen mellem mennesker. Omdrejningspunktet i etnografiske studier er således dataindsamlingsmetoder, der gør det muligt at studere sociale fænomener i deres naturlige omgivelser, primært deltagerobservation og interview (der enten kan foregå som uformelle samtaler eller semi-strukturerede interviews) kombineret med en forståelsesorienteret analytisk strategi. Der lægges her vægt på væsentligheden af at bygge på og bevare erfaringer som kvalitative helheder, inklusiv de emotionelle eller sansemæssige indtryk, de er forbundet med. Der er således i en etnografisk tilgang en betoning af "at være der" som vej til at skabe viden om den virkelighed man har i fokus, hvilket også inkluderer at man på egen krop kan mærke fysiske og følelsesmæssige påvirkninger af udsagn og handlinger i den praksis man studerer. I dette tilfælde var "at være der" dobbelt: det betød at være der i det digitale rum, dvs. have adgang til det, der blev delt på platformen, men også at have adgang til fysisk samvær mellem dem der bruger platformen og til den mening borgerne tillægger dette samvær og hvordan det får betydning for dem i deres hverdagsliv.

Udgangspunktet i etnografisk metode indebærer dermed, at man eksplicit forlader ideen om en forskerposition som er udenforstående og objektiv i forhold til den studerede praksis. Det betyder imidlertid ikke at det er et mål, at forskeren blot lader sig opsuge i den studerede praksis. 
Czarniawska (2007) har (blandt andre forskere) argumenteret for, at det netop er gennem forskerens deltagende 'fremmedhed' at forskningsmateriale genereres, dvs. dét, at forskeren netop qua at være udefrakommende overraskes, undres, og bemærker andre ting end de personer, der til daglig er en del af den studerede praksis. I dette projekt har vi brugt denne 'fremmedhed' aktivt som udgangspunkt for dialog ved at sende de dele af det empiriske materiale (udsagn fra interviews, fotos, observationsnoter), som forskerne særligt bemærkede, tilbage i gruppen af borgere med henblik på at vække deres videre tanker, associationer og den mening, det genererer i deres hverdagskontekst. Således blev der efter syv måneder gennemført en workshop med en større gruppe deltagere, hvor brudstykker fra interviews og observationer tjente som udgangspunkt for en videre dialog. På den måde har det også haft en betydning at projektet er udsprunget i codesignfeltet, der bygger på etnografisk undersøgelse af situeret praksis, men netop også på etablering af deltagelsesmuligheder i den forsknings- og udviklingsmetodiske tilgang (Binder \& Brandt, 2008).Ved at sende brudstykker af empirisk materiale i spil i workshoppen, har vi forsøgt at bruge empirisk materiale såsom interviews og fotos, ikke blot i et repræsenterende perspektiv, men som en sti ind i helhedsorienterede erfaringer (Pink, 2009). Derved har vi brugt udsagn og fotos til at vække multiple erfaringer til live hos borgerne og bruge dem som udgangspunkt for deres meningsanknytning.

Dataindsamlingen foregik over et år (september 2017 - september 2018), hvor 11 personer (ud af ca. 20 gruppedeltagere) og den kommunale koordinator havde adgang til en digital platform. Ud over borgerne og koordinatoren havde to forskere adgang til platformen. I alt består data af observationer fra 14 feltbesøg, 7 semistrukturerede interviews, uformelle samtaler samt lydoptagelser og noter fra 2 timers workshop. Data inkluderer også kvantitative data fra interaktioner på platformen, herunder antal sendte og læste meddelelser. Interviews og workshop blev lydoptaget og efterfølgende transskriberet ordret. Observationer og uformelle samtaler blev systematisk registreret skriftligt i en logbog.

\section{Analyse: Det, fællesskabet mødes med, om og for...}

I analysen undersøger vi nu med afsæt i Elkjær og Simpsons $(2011,2009)$ forståelse af social praksis som en relationel, transaktiv proces, hvordan fællesskabelsen konstitueres gennem menneskers handlinger og meningsskabelse i en proces, der er sammenvævet med andre, medkonstituerende elementer så som steder, ting, teknologi og tid. Vores teoretiske ramme giver derved blik for, hvordan fællesskabelsen konstitueres som en situeret praksis, hvori mening emergerer over tid i transaktioner mellem aktørers oplevelse af sig selv og situationer (Elkjaer \& Simpson, 2011). I analysen ser vi på 1) hvad de mødes om (handlinger, aktiviteter), 2) hvad de mødes med (erfaringer, levet liv) og 3) hvad de mødes for (mening, liv, mulighed, tilhørsforhold), som tre analytiske greb til 
at undersøge og begrebsliggøre, hvordan fælleskabelse konstitueres. Dernæst ser vi på 4) de rumlige, materielle og temporale elementer som medspillere i konstitueringen af et fælleskab.

\section{Det, de mødes om}

Det ville måske være nærliggende at sige, at Lungenetværket som fællesskab består gennem de aktiviteter, aktørerne mødes om. At det er træningen, foredrag eller måske kaffen, der gør det. Nedenstående analyse peger på, at aktiviteterne er medkonstituerende for fællesskabelsen, men også på at fællesskab opstår i samspil med flere elementer, så som aktørernes erfaringer, drømme og håb for fremtiden, ideer og begreber om aktiv aldring, sundhed, mv.

I Lungenetværket pågår i en række aktiviteter, som vi her med et socialt praksisperspektiv vil betragte som handlinger. Først og fremmest kan vi få øje på træningen, som finder sted med fast, ugentlig frekvens og af samme varighed på to timer. Træningen tilrettelægges af koordinator eller borgerne selv, hvis koordinator er forhindret. Træningen er i nogen grad tilrettelagt med et særligt fokus på at styrke lungekapacitet eller lette vejrtrækning. Det er styrkeøvelser, øvelser, der har fokus på balance, koordinering og konditionstræning. Ud over træningen pågår der også aktiviteter rettet mod 'sundhed' mere generelt, som fx måling af puls, udholdenhed, o.l. Der er foredrag om rygestop, om kost relateret til mennesker med funktionsnedsættelser i hjerte og lunger. Der er tidsrum, hvor borgerne taler sammen om, hvad det vil sige at have nedsat lungefunktion, om KOL-diagnosen, mv. De taler om erfaringer med indlæggelser, genoptræningsforløb, hvordan man håndterer eller kommer i kontakt med sundhedsprofessionelle, hvilke behandlingsmuligheder der findes, hvilken mad man spiser, og hvordan man får protein nok, når appetitten svigter.

De mødes om træningen som en central aktivitet, der knytter sig til pludselig at opleve at måtte 'sætte tempoet ned', fordi kræfterne ikke slår til og mødet med omgivelserne - som fx trapper til 4.sal - skaber modstand. Aktiviteten træning har en klar rettethed mod resultater som styrke, lungekapacitet, balance og kondition, som understreges gennem visuelle/materielle tegn, fx antal streger på tavlen for, hvor mange omgange man klarer i cirkeltræningen, hvordan de forskellige øvelser gennemføres eller som tal ved måling af lungekapacitet.

Et par gange har deltagerne selv taget initiativ til aktiviteter og mødtes til julefrokost og en enkelt gang til en spontan grillfest. Som oftest er det dog det at drikke kaffe i Aktivitetscenterets kantine, som er en fast tilbagevendende aktivitet i Lungenetværket, og aktiviteten 'at drikke kaffe' trækkes frem igen og igen i det empiriske materiale. Faktisk har vi ikke tidligere haft empirisk materiale med så meget kaffe i. Kaffen fremhæves - fx i citatet herunder - som en helt central komponent i det, der bliver fælles: 
Dorte: 'bagefter så køber vi en kande kaffe og sidder og hygger os og hører, hvordan det går, og hvad man skal lave, og hvad man har lavet'. Så er vi toet på hinanden. I stedet for - her [i traening] der får vi jo somme tider besked på at holde vores kaft. Ikke også? (latter). Og det var også [over kaffen], vi fandt ud af, at vi ville til grillfest i sommer. Så vi var vel en 10-12 stykker til grillfest her $i$ huset. Uden at komme sammen privat, nogen af os.

Som med træningen, opstår oplevelsen af fællesskab ved at gøre noget sammen, gennem deltagelse i en fælles aktivitet på samme tid og sted. Kaffe som fælles handling eller aktivitet adskiller sig samtidig fra træningen i kraft af den mening eller rettethed, handlingen tillægges og derigennem aktørernes mulige oplevelse af sig selv i kraft af deres deltagelse heri. At drikke kaffe er en aktivitet, der er tilpas åben og tilpas velkendt fra hverdagslivet til, at man kan deltage uden at det er fastlagt hvordan eller hvem man er, hvis man deltager. Uden at kræve noget særligt. Modsat træningen, hvor deltagerne i en eller anden grad forventes og forsøger at deltage aktivt i de øvelser, der foreslås, er kaffen mere åben for forskellige deltagelsesformer og uden en tydelig intention om noget der skal lykkes eller et bestemt formål. Kaffeaktiviteten medkonstituerer en mere åben deltagelsform som tilbyder mange fortolkninger af hvorfor man deltager og hvem man er eller bliver til gennem deltagelse i aktiviteten. Kaffe-aktiviteten udvider en mere snæver position (aktualiseret gennem træningen) og rummer muligheden for at fremtræde eller 'gøre' sig selv som andet og mere end en syg krop.

Citatet ovenfor illustrerer desuden, hvordan en episode med en bestemt aktivitet (kaffen efter træningen) giver anledning til en anden aktivitet (grillfesten), som efterfølgende giver anledning og mening til nye fælles aktiviteter (over kaffe, under træningen, ved forsøg med at bruge den digitale platform). Fællesskabelse fremtræder her som en proces, der er udstrakt over tid og sted. Hvert 'nu' indeholder potentialet for at forstå og genforstå, opretholde eller forandre det, fællesskabet samler sig om. Med Deweys blik, her fortolket af Bernstein (1960), træder fællesskabelsen frem som en bevægelse mellem og i enheder:

\footnotetext{
"In transaktion, the components themselves are subject to change. Their character affects and is affected by the transaction, [hence], they are not independent: they are phases in a unified transaction."
}

(Bernstein, 1960, s. xl, her i Elkjaer \& Simpson 2011, s. 21)

Handlinger - eller aktiviteter - kan betragtes som elementer i sociale situationer, hvor igennem deltagere udveksler og former mening og erfaring om hvem de er, og hvad situationen betyder. Det vil sige, at det er i transaktionen at handlingen samtidig får mening og giver mening som element $\mathrm{i}$ fællesskabelsen. 


\section{Det, de mødes med}

At være en del af fællesskabet handler om andet og mere end om at kunne eller ville deltage i aktiviteter som træning, foredrag eller kaffedrikning i kantinen bagefter. De aktiviteter, aktørerne mødes om, er ikke helt tilfældige eller udskiftelige med en hvilken som helst anden aktivitet. Kaffen, træningen, foredrag i 'cafeen' og grillfesten er nært knyttet sammen med det, deltagerne mødes med: de kropsligt indlejrede livserfaringer og oplevelser, deltagerne/aktørerne har med sig.

Deltagelse i Lungenetværket er gratis og forhandles ikke gennem et kontingent, der tilsiger, at har du betalt, er du med; har du ikke betalt, er du ikke. Adgang tildeles heller ikke via en henvisning eller visitation (eksempelvis fra kommunen eller sundhedspersonale i det sekundære sundhedsvæsen). Fællesskabelsen konstituerer sig gennem en proces, hvor det ikke nødvendigvis er åbenlyst, hvem der er velkommen, eller hvordan man kan gøre sig genkendelig som del af fællesskabet:

I: hvad er det der gør, at man har lov til at komme her...? Er det ligesom vejrtroekningsproblemerne eller hvordan er det, man kommer ind i Lungenetvoerket? Inge: Jeg har haft mange overvejelser: er man nu vedkommende eller er man ikke vedkommende, men så er jeg jo kommet ind... Marta: Det gør man jo altid i starten og så kommer det stille og roligt.

At deltage og opleve sig som en del af fællesskabet handler om, hvorvidt hver enkelt deltager oplever sig genkendt og vedkommende som en del af vi-heden, hvorvidt de kan forbinde sig selv og egne erfaringer med betydningen af de handlinger, som aktiviteten tillægges af gruppen. At blive en deltager i fællesskabet er en proces, der opstår over tid frem for et medlemskab, der kan tildeles eller opnås en gang for alle.

Aktørerne i Lungenetværket mødes med det til fælles, at de i forskellig grad har gjort sig levede, kropslige erfaringer med, hvad det vil sige at have nedsat lungefunktion. Med det at tabe pusten, når kroppen møder trapper. Med åndenød. Med ikke at kunne gøre ting, man tidligere kunne. Med møder med omgivelsernes forventninger om, hvad man burde være i stand til. Det er oplevelser, som en stor del af gruppens deltagere genkender hos hinanden.

Sonja: det at høre om [I] andres hverdag, det giver mig noget. Selvom vi ikke er ens, er der mange lighedspunkter. Så føler jeg, at det ikke bare er mig, der er helt tosset. Det er faktisk helt normalt. Jeg har et kortspille-vennepar. Og de kan slet ikke saette sig ind i, hvordan jeg har det. Og så har jeg sagt til dem 'prøv engang at tage et sugerør i munden og kun troekke vejret igennem det'. Nej, det kunne de ikke se nogen grund til. [...] Så det er meget rart, man har ikke noget her at stå og fortcelle [i Lungenetvarket] - jamen jeg havde bare ikke overskud til at komme, fx om onsdagen. For det ved alle sammen godt, hvorfor jeg ikke havde. Det er meget rart. 
Erfaringer med ikke at kunne finde overskud mentalt eller fysisk til at deltage i sociale aktiviteter (som kortspil) og med at møde kritiske eller uforstående spørgsmål og bemærkninger fra omgivelserne, hvis man ikke deltager, skaber oplevelsen af eksklusion. Ved at tage del i Lungenetværkets aktiviteter med netværkets andre aktører, kan Sonjas oplevelse af anderledeshed - og derigennem adskilthed - spejles og blive til oplevelse af lighed, normalitet og vi-hed.

En essentiel del af oplevelsen af inklusion og fællesskab opstår i kraft af forestillingen (i nuet) om, at udeblivelse fra aktiviteter (i en hypotetisk fremtidig situation) ville blive mødt med forståelse og ikke ville betyde eksklusion. Fremtidige, hypotetiske handlinger (Mead, 1932) indgår i situationens meningsskabelse, hvor fleksibel deltagelse aktualiseres som en særlig kvalitet og social norm ved dette fællesskab. Fællesskabelsen finder sted gennem en sammenfiltring i nuet af erfaringer (fra fortiden), drømme og håb (for fremtiden) med aktiviteter (træning, kaffe, grillfester, foredrag), på tværs af deltagernes ligheder og forskelligheder.

Men selvom samtaler over kaffen om erfaringer med nedsat lungefunktion giver anledning til oplevelsen af vi-hed, kan stræben efter at forme fællesskabelse gennem en pluralitet af erfaringer og rette opmærksomheden i en anden retning også ses at være tilstede:

Sonja: men jeg vil så også sige, at jeg går meget sjoeldent ind på [Lungeforeningens hjemmeside]. Fordi en gang imellem så hœenger al den sygdom mig langt ud af halsen. Fordi man gider - Lotte: nej man gider ikke, vel?

Det, de mødes med, er en stræben efter at balancere oplevelsen af mening, så man ikke bare holder sig i live (en stræben som ville forbinde sig med diskurser om sundhed og et aktivt ældreliv) men føler sig i live. Deltagernes erfaringer og kropslige/mentale rejse gennem tid og rum bringer spændingsforholdet mellem sygdom/sundhed, liv/død og udenfor/indenfor med ind i Lungenetværket. En af deltagerne fortæller om, hvordan hendes mand kom på plejehjem, efter han fik en blodprop og slutter: Det er meget vigtigt for mig at få noget indhold i mit liv... Levede erfaringer med ægteskab, arbejdsliv, sundhed/sygdom, liv/død spiller med ind i fællesskabelsen: gennem aktiviteterne flettes aktørernes fortidige erfaringer og forestillinger om eget liv sammen og trækker tråde mellem det, der har været og det, der (endnu) kan komme.

Som da den digitale platform introduceres som element i Lungenetværket sammen med eksempler på, hvad andre grupper af seniorer har brugt en digital platform til. Her opstår anledning til refleksion og nye forestillinger om 'det potentielle', hvor fortidens oplevelser projiceres over på forhåbninger om fremtiden. Erfaringer fra fortiden med landskaber og kropslige begrænsninger 
indgår i fællesskabelsen af forestillinger om, hvad man fremover kan være fælles om i Lungenetværket:

Marta: Man kunne jo sagtens dele nogle ruter [via platformen]. Der kunne man jo lave nogle forslag med forskellig longde og så videre, sådan så - fx så går jeg meget ude på Revet. Laila: [afbryder] jamen der - jeg tør slet ikke at gå sådan nogen steder hen, hvor der ikke kan komme ambulance eller hvor jeg kan få hjoelp, hvis jeg får problemer. Det er helt udelukket for mit vedkommende! I: så man kunne finde nogle ruter som...? [en foreslår en anden konkret rute og flere stemmer $i$ - 'der er også fortet', 'eller bare en tur på stranden eller', 'jeg synes også...' og de taler om hvilke ugedage, de kan].

De erfaringer, som aktørerne bringer med sig, er centrale komponenter i den kollektive skabelse af forventninger og forestillinger om, hvad fællesskabet kan blive i fremtiden. Det, aktørerne mødes med spiller en fundamental rolle i konstitueringen af fællesskabelsen gennem afvejning af, hvilke aktiviteter fællesskabelse kan bestå gennem, med andre ord hvilke praksisser, der kan rumme aktørernes selvforståelse og forventninger. Fællesskabets handlinger skal ikke forstås som noget, der bygger på enighed eller fælles overbevisning, men som noget, der "foretages med en vis grad af kollektiv anerkendelse af en raison d'être" (Hernes, 2017, s. 99). En del af aktørernes erfaringer skaber resonans og giver grundlag for, gennem aktiviteter som træning og kaffe, at opleve vi-hed, inklusion og at være normal. Samtidig er en del af det, der bringes ind, netop deltagernes forskellighed: det er inspiration og mulighed for vanebrud og derved udvikling af de handlinger, fællesskabelsen kan opstå af.

\section{Det, de mødes for}

Det tredje blik, vi lægger på casen, er fokuseret for at indfange det, deltagerne mødes for. Det, der kan opstå og findes i mellemrummet mellem aktørernes erfaringer og handlinger. I det foregående afsnit fandt vi, at konstitueringen af fællesskabelsen ikke alene kan ses som værende lig med de af koordinator iværksatte handlinger og aktiviteter (rette mod mål som sundhed, rygestop, kostomlægning, øget lungekapacitet, etc.) eller aktørernes egne iværksatte handlinger (som kaffe og grillfest, ideen om gåtur på revet). Fællesskabelsen konfigureres bredere og mere diffust i tid og sted og gennem en sammenfiltring af aktiviteter/handlinger og aktørernes erfaringer, drømme og håb:

Interviewer: Så i virkeligheden kan det vaere mange forskellige aktiviteter [I mødes om] ...? Vera: Ja det er lige meget... For mit vedkommende - når man er alene - så får man lidt rygstøtte, lidt opbakning.

At blive genkendt (som helt 'normal') og at opleve genkendelse, rygstøtte og opbakning fremhæves af flere af deltagerne. De lægger vægt på kvaliteten ved at kunne dele oplevelsen af at holde sig i 
live - og måske i kraft af at dele dette netop at føle sig i live. Vi-heden opstår, når aktørerne deler erfaringer og selvforståelse i spændingsfeltet mellem deltagelse i forskellige aktiviteter og deres kropslige erfaringer, og forhåbninger til livet. Erfaringer ( $\mathrm{f} x$ med vejrtrækning), som $\mathrm{i}$ andre sammenhænge kolliderer med forventninger til egen formåen og til livet og kan opleves som forkerte, dårlige eller vanskelige, bliver i samspillet her til en kapacitet, som får en særlig betydning i deltagelsen ved at muliggøre støtte, opmuntring, og at man kan hjælpe andre:

Laila: jeg har svart ved at komme ned til skoene efterhånden pga. presset på lungerne. Så havde Sonja lige et skohorn, hun tog med, når man skal skifte fra støvler til kondisko, ikke? Altså det var sgu da dejligt, synes jeg. Sonja: ja ja. Interviewer: I forstår lige de der detaljer med hinanden, og hvad der bliver svaert? Lone: Det er det man kan sige sådan, sammenhold, ikke? Man hjoelper hinanden med små ting som gør livet nemmere. Hvad har man venner til?

Oplevelsen af at deltage i fællesskabelse knytter an til oplevelse af at være i live, at være nyttig, at være noget for nogen (hvad har man venner for?), og ser ud til at være nært forbundet med en kropslig, situeret tilstedeværelse i tid og sted. I et her og $n u$ giver spejlingen af kropslige erfaringer med åndenød og kondisko (Sonja genkender Lailas anstrengelse) anledning til at træde til som en ven (deler sit skohorn) og til at være den, der modtager en venlig gestus (Laila); en, man kan være ven med. Men deltagelse i fællesskabelsen kan også tage form af en mindre aktiv, mere lyttende eller absorberende deltagelsesform:

Sonja: jeg synes det er meget rart at høre om andres hverdag. Hvad den går med. Hvor man snakker om - kryds og tvaers, ikke? Det synes jeg faktisk er meget rart at sidde og slappe af og høre på. Du behøver ikke at deltage selv, men du kan suge noget til dig. [flere istemmer ja].

Fællesskabelsen konstitueres her gennem forskellige grader og former for deltagelse, hvor det at lytte medkonstituerer muligheden for en anden til at blive den, der fortæller eller inspirerer. Erfaring er både aktiv og passiv og består ikke alene gennem summen af fortidens handlinger (Simpson \& Elkjaer 2011, s.13). Fortællinger om udfordringer, oplevelser, sejre og nederlag tilbyder et potentielt rum for at skabe og genskabe erfaring med livet og hvem man er - ved at dele sine erfaringer eller ved at bare lytte og at være i periferien og opleve sig selv gennem forskellighed eller genkendelse. Det, de mødes for at dele, er de små ting i livet - venskab, inspiration, et grin - for at føle sig i live gennem samværet med hinanden og ved at bekræfte livet gennem samtaler, aktiviteter og drømme for fremtiden. Men ligesom fællesskabets aktiviteter aktualiserer livet, således aktualiseres også døden, som en af deltagerne siger: noget af det, der er svaerest med sådan nogle grupper [er, når] folk ikke kommer mere. Altså ... det er noesten ikke til at have, vel? 
Livet og døden er her sammenfoldet og kontinuerligt aktualiseret i kraft af fællesskabets specifikke konstitution: aktiviteterne, aktørernes erfaringer og livssituation og i kraft af det, der skabes i transaktionen. Lungenetværket rummer tilstedeværet af døden som noget, der er tæt på. Det er medkonstituerende som en særlig kvalitet ved deltagelsen i fællesskabelse, at erfaringer og handlinger skaber rummelighed for intensiteten i spændingen liv/død. Fællesskabelsen muliggør en'væren med' et vanskeligt og tabuiseret emne som døden, og i delingen af fortællinger om erfaringer med hvad det vil sige at leve i spændingsfeltet mellem aktualiseret liv og død, træder humor frem:

Interviewer: har det nogen saerlig betydning, at du deler sygdom med de andre der kommer her? Peter: Ja det er jo... så ved man jo, hvorfor Marta ikke fiser op ad trapperne. Marta: [griner] nej det gør jeg jo ikke... Peter: det er også svoert at komme ned... Men så skal du bare loere at flyve ... man skal bare lande bedre... det var det, jeg manglede.

Fællesskabelsen indebærer en rummelighed og elementer af humor og nærvær fremfor præstation, selvom samværet implicit indeholder et element af at spejle sig i andres sundhed, sygdom, livsindhold eller 'hvor langt man er' i KOL-forløbet (og livet). Det, de mødes for, kan vi få øje på som 'at være i live', at livet stadig er værd at lægge planer for, at være nogens ven, at være normal. Med andre ord overskrider det, de mødes for, langt de mål og formål, der kan rummes indenfor rammerne af sundhed, træning eller andre af de mål, en offentlig myndighed ville stille.

\section{Dimensioner i fællesskabelse som social, situeret praksis}

I analysen har vi undersøgt fællesskabelsen som en bevægelse i en lokal, social praksis ved brug af et relationelt og transaktivt blik (Simpson 2009). Derved forskød vi fokus fra individ og afgrænsede redskaber som teknologi, til relationer og transaktionen mellem aktører, ting, steder og tid og til den gensidige proces, hvorigennem fællesskabelse tillægges mening og betydning.

Nedenstående model (Figur 1) illustrerer fællesskabelse gennem fire gensidigt forbundne og kontingente dimensioner: 1) en handlingsdimension, der indfanger elementer af aktiv, situeret praksis, 2) en erfaringsdimension, der giver blik for betydningen af erfaring som mere og andet end individuel 'viden'. 3) Fællesskabelsens forestillingsdimension, der indfanger et fundamentalt element, nemlig transaktion som et generisk træk ved væren (Bernstein, 1960): Elementer af fællesskabelsen konstitueres gennem deltagernes drømme, håb og forventninger i transaktion med sociale situationer. 


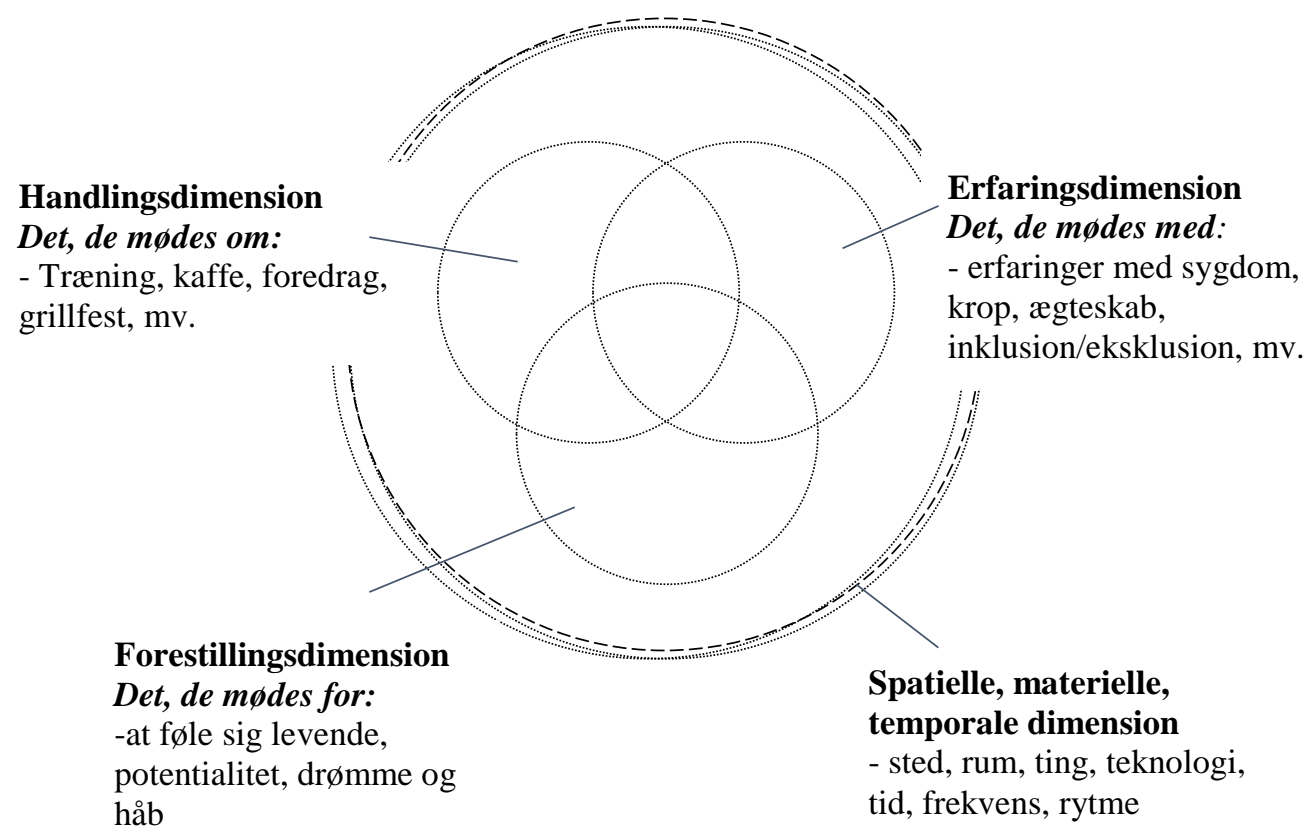

Fig. 1 Dimensioner i fællesskabelse som social, situeret praksis

Den fjerde dimension rummer de fysiske/materielle, temporale og spatiale elementer, der indgår i fællesskabelsen som en social, situeret praksis. Denne dimension udfoldes nedefor med særligt henblik på teknologien.

Elementerne i modellens dimensioner er kontingente, hvilket vil sige, at de interagerer, men de er ikke knyttet sammen i en forudbestemt orden. Ved at betragte fællesskabelsen med et relationelt og transaktivt blik, træder fællesskabelse frem som en bevægelse, hvor dimensionernes delelementer påvirker og påvirkes gensidigt. Fællesskabelsen kan dermed indfanges gennem et blik på det, der sker i mellemrummet (relationen) mellem delelementerne, fremfor gennem undersøgelse af elementerne i sig selv og hver for sig.

\section{Teknologien som medkonstituerende element i fællesskabelse}

Fællesskabelsens dimensioner spiller sammen med og betinges gennem de spatielle, materielle og temporale betingelser, der er til stede. Disse er fx den faste mødefrekvens, aktivitetscenterets lokaler, stole, borde og kaffe, ligesom casens teknologi (platformen) indgår som med- og modspiller i fællesskabelsen. I det følgende fokuserer vi på at undersøge, hvordan teknologien fremstår som med- og modspiller i konstitueringen af fællesskab. Som nævnt i beskrivelsen af casen, blev platformen kun i begrænset omfang bragt i anvendelse i Lungenetværket. Dette skyldtes en kombination af blandt andet tekniske fejl i platformens software, den specifikke platform 
(usability), tilsammen med deltagernes erfaringer med og holdninger til ICT. På trods af dette gav introduktionen af platformen anledning til bevægelse i fællesskabelsen:

I: ja. Hvad ville du bruge den [LM platformen] til så? Sonja: jamen den kunne jeg da godt finde på hvis jeg sidder en dag, måske en søndag eftermiddag og vejret det er godt, men jeg kunne da godt toenke mig at gå en lille tur. Der var måske nogen, jeg kunne hive med? Der var nogen, der måske kunne hive mig op? Det kunne jeg - ja. Interviewer: der ville du kunne få fat i et par stykker? Sonja: ja, ja. Eller hvis der er nogen, der ikke har vaeret her. [nogen] jeg ikke har set loenge: lige skrive til dem 'hej, hvordan går det med dig?' 'Er det noget rigtig skidt eller har du bare ferie?'

Med et transaktivt blik får vi i eksemplet her øje på platformen som medkonstituerende element, der skubber til vaner i den sociale praksis. Vaner er de tillærte dispositioner for bestemte reaktioner på bestemte omstændigheder, eller udtryk for sociale normer (Elkjaer \& Simpson, 2011). Samtidig med at vaner er stabiliserende i kraft af dette, rummer vaner samtidig muligheden for forandring over tid. I eksemplet ovenfor er den digitale platform medkonstituerende i fællesskabelsen som en drøm om muligheder for at udvide sin kontakt til fællesskabet (nye erfaringer og forestillinger) og for at lægge en ny aktivitet ind i det, fællesskabet gør sammen (nye handlemuligheder). I det nu, som situationen ovenfor beskriver, giver platformen anledning til skabelse af fremtidsforestillinger, hvor (hypotetiske) handlinger projiceres frem i tid og giver anledning til at drømme om eller håbe på mulighed for vi-hed, fx at udvise omsorg for andre og for selv at modtage omsorg og interesse.

Men ligesom platformen kan producere anledninger til drømme og håb, kan transaktionen mellem platformen og øvrige elementer i fællesskabelse give anledning til at noget opleves at true eller udfordre fællesskabelsen, som en deltager giver udtryk for: Dorthe: [afbryder en anden der taler om platformen] så laenge det kun skal gå på sådan noget [computer], så er vi jo nogen, der bliver lukket ude! Mødet med platformen og forventninger til 'hvordan vi plejer at gøre' støder sammen og giver anledning til bekymring og frygt for eksklusion fra deltagelse i fællesskabelsen.

Sonja: jeg sidder og tonker på, at nu er den telefonliste. Hvis vi bare fik den telefonliste alle sammen. Lone: ja. Dorthe: ja det ville voere en god idé. Sonja: ikke? Også fordi så kunne vi altid ringe til hinanden. Jeg kunne ringe til dig, hvis jeg ser noget på Facebook. At nu er der altså noget - et arrangement - som måske interesserede os. Så kunne man ringe og sige 'hvad - vil du med?' Det kunne jeg da godt finde på. Derfor så synes jeg, at vi skulle have de telefonnumre alle sammen. Og så kunne jeg da godt tonke mig, at vi stadigvak var på Facebook eller på [LM-platformen].

Det, der indimellem produceres, og det, der indimellem trues eller udfordres i teknologiens interaktion med de øvrige komponenter i vores empiri, kan beskrives som 'fornemmelsen for mulighed' eller det forudgribende aspekt af livet. Dorthe udtrykker i citatet sin bekymring for, at 
inklusion af teknologien vil betyde eksklusion af fællesskabet for hende. Teknologien står derved i modsætning til Dorthes erfaringer og fornemmelse for mulighed i forestillinger om fremtiden. I samme citat giver Sonja udtryk for teknologien som noget, der for hende giver anledning til en fornemmelse af fremtidige muligheder for fællesskabende aktiviteter. Teknologien som medkonstituerende element giver i mødet med Sonjas erfaringer anledning til en forestilling om muligheden for at forbinde sig tættere til fællesskabet. Transaktionen mellem deltageren og platformen etablerer en erfaring i nuet, der knytter an til tidligere erfaringer og til drømme om fremtiden: til forestillinger om nye muligheder såvel som tab af eksisterende.

\section{E. Diskussion}

På baggrund af analysen ovenfor kan vi nu indkredse fællesskabelsens dynamik mere præcist: Snarere end at være et spørgsmål om enten det faste (roller, mål, fastlagte aktiviteter og mødetider) eller det flydende (drømme, håb, ukendte fremtider), sker fællesskabelsen i en dynamik hvor begge sider kan opretholdes og interagere. Fællesskabelsen hviler både på at der er stabiliserende elementer, herunder at der er indrammet tematiseringer, tidspunkter og rum for mødet mellem borgere, og på at der er en fleksibilitet - et rum af ubestemthed, hvor det er mere åbent hvem man er og bliver til som borger, og hvordan man deltager, end det fx er når man er patient $i$ et sundhedssystem.

Fællesskabelse og oplevelsen af vi-hed opstår således som en fælles bestræbelse, hvori en flerhed af elementer - aktører, ting, steder, teknologi og tid - indgår. Fællesskabelsen kan ikke alene indkredses som de handlinger og aktiviteter der er sat i gang af den offentlige koordinator (rettet mod mål som sundhed, rygestop, kostomlægning, øget lungekapacitet, etc.) eller af borgerne selv (som fx kaffesnak og grillfest). Fællesskabelsen konfigureres bredere og mere diffust i tid og sted og gennem en sammenfletning af konkrete aktiviteter/handlinger og aktørernes erfaringer, drømme og håb. Fællesskabelse må således forstås som noget der opstår $i$ tid: det er en kontinuerlig bevægelse, hvor udvalgte fortider reaktualiseres og sammenflettes (tidligere erfaringer vækkes til live og forbindes) og giver anledning til at fremtider forudgribes på bestemte måder og knyttes sammen (drømme, håb eller bekymringer). Analysen peger således på fællesskabelse som en proces der er samtidig potentielt reproduktiv/stabiliserende og innovativ/kreativ, og som udspiller sig i tæt transaktion med specifikke steder og rum. Kontinuitet og forandring opstår ud af handleepisoder, hvor tiden punktueres af begivenheder af socialt konstruerede forståelser (Elkjaer \& Simpson, 2011) (fx under kaffen efter træning) og gennem tilbagevendende opmærksomheder (fx som artikulationen om grillfesten, træning, etc.).

Det offentlige som aktør kan her spille en vigtig rolle i forhold til at initiere og fastholde de stabiliserende elementer - rum, materialitet, tematiseringer - men må samtidig følge og spille ind i 
fællesskabelsens egne dynamikker uden en mulighed for entydigt at styre dem mod bestemte resultater inden for bestemte tidshorisonter. Modsat eksemplet $\mathrm{fx}$ med telemedicin, hvor sundhedspersonale tilrettelægger og styrer processen, er borgerne i casen her medskabere ikke kun af processen, men også horisonten for værdiskabelsen. Udkommet af processen er her ikke en service eller en ydelse. Det er en mere kompleks størrelse, hvor aktørernes erfaringer, handlinger og forestillinger sammenflettes. Den værdiskabelse, der finder sted og som fællesskabet emergerer omkring, overskrider således forudbestemte mål om sundhed; det er en værdi der bliver til i en horisont, der forbliver uafsluttet og i bevægelse.

Betragter vi fællesskabelse som vej til velfærdsudvikling, bliver det offentliges facilitering af fællesskabelse et spørgsmål om at forstå og påvirke processer, der muliggør at borgere kan mødes om, med og for det der er væsentligt i tilblivelsen af disse borgeres velfærd. Det at facilitere fællesskabelse ligger dermed i et felt mellem på den ene side at have en rettethed imod bestemte typer af offentlige mål og værdiforståelser med dertil hørende målgrupper, og på den anden side at bryde med selv samme rettethed og åbne op for processer med aldrig færdige værdihorisonter og målgruppeforestillinger med rum for ubestemhed. Som offentlig aktør har man her nogle særlige muligheder for at deltage - men kan samtidig aldrig entydigt styre - orkestreringen af tid og rum for sådanne sammenfletninger af handlinger, erfaringer og forestillinger der er væsentlige i borgeres liv.

\section{F. Konklusion og afrunding}

Ideen om, at offentlige aktører kan lede samskabelse af velfærd gennem at mobilisere og facilitere borgerfællesskaber, vinder terræn i det kommunale landskab. Den analyserede case føjer sig således ind i rækken af initiativer, der bygger på fællesskabet som en ressource i velfærdsudvikling. I casen ser vi, hvordan denne ide indebærer en udviskning af skellet mellem resultat og proces i offentlig velfærdsproduktion: Den kommunale koordinator leverer ikke entydigt en social service, ligesom han heller ikke visiterer til en særlig ydelse. Han deltager i fællesskabelsen og hans rolle er dermed på en og samme tid betinget af - og medvirkende til - fællesskabelse, om end han deltager på andre præmisser end de øvrige deltagere. Grænsen mellem udbyder og modtager af velfærd sløres således, idet velfærd i mindre grad er en 'ydelse' der leveres og i højere grad består i selve processen, hvori relationen skabes og genskabes. Betydningen af at 'være der' træder her frem, dvs. at være tæt på og deltage i den lokale aktivitet for at kunne sanse, forstå og koble sig på, hvordan aktiviteter spiller sammen med borgeres erfaringer, håb og forestillinger.

Når samskabelse som tilgang til social innovation sker gennem facilitering af borgerfællesskaber, får det således en række implikationer for, hvordan velfærd og velfærdsydelser kan udvikles, produceres, ledes og styres. Initiativer, som det vi ser i casen, involverer stadig i større eller mindre 
omfang det offentlige, men en række grundlæggende størrelser ændrer sig, fx målgruppebegrebet, målfastsættelse og resultatvurdering. Bestræbelsen på at skabe borgerfællesskab påvirker ikke bare måden at udvikle ydelsen på, den forandrer ikke alene roller og relationer mellem civilsamfund og offentlig sektor, men også hvad det ønskede resultat kan være, og hvilke værdiforståelser, der kommer i spil. Selve horisonten for værdiskabelse bliver transformeret. Fællesskabelsen kan her hverken reduceres til bestemte aktiviteter eller resultater, men konfigureres bredere og mere diffust i tid og sted i sammenfletninger mellem konkrete aktiviteter/handlinger og aktørernes erfaringer, drømme og håb.

Det offentlige som aktør kan her spille en vigtig rolle i forhold til at initiere og fastholde de stabiliserende elementer i en sådan proces, men må samtidig spille ind i fællesskabelsens egne dynamikker uden en mulighed for entydigt at styre dem mod bestemte resultater inden for bestemte tidshorisonter. Det bliver her vigtigt at have et sprog og en tænkning, der kan rumme fællesskabet som bevægelse snarere end som en enhed, og som relationel dynamik snarere end som summen af individuelle kapaciteter. Med denne artikel, og påpegningen af handlings- erfarings- og forestillingsdimensionens betydning i fællesskabelsesprocesser i tid og rum, har vi forsøgt at bidrage til udviklingen af et sådant sprog.

\section{Tak}

Artiklens er blevet til på baggrund af MATURE-projektet, der har til formål at give ny viden om forskellige grupper og generationer af ældre og deres behov og præferencer, samt at afprøve en række teknologier, der kan gøre en forskel for ældres livskvalitet. Innovationsfonden har investeret i MATURE projektet tilsammen med de deltagende partnere. MATURE-projektet ledes af VIVE - Det Nationale Forsknings- og Analysecenter for Velfærd. Tak til Lungenetværket for deltagelse i projektet og til Ulla Skjødt, Lene Teglhus Kaufmann, og Jeanette Præstegaard fra Professionshøjskolen Absalon for kommentarer og diskussion af artiklens indledende ideer. 


\section{Referencer}

Agger, A., \& Tortzen, A. (2015). Forskningsreview om samskabelse. Roskilde.

Agger, Annika, Tortzen, A., \& Rosenberg, C. (2018). Hvilken vaerdi skaber vi med samskabelse? Aarhus: Professionshøjskolen Absalon.

BEPA. (2011). Empowering people, driving change. Social Innovation in the European Union. Luxembourg.

Bernstein, R. J. (1960). John Dewey. On experience, nature and freedom. Representative selections. New York: The Liberal Arts Press.

Binder, T., \& Brandt, E. (2008). The Design:Lab as platform in participatory design research. CoDesign, 4(2), 115-129. https://doi.org/10.1080/15710880802117113

Crepaldi, C., De Rosa, E., \& Pesce, F. (2012). Literature review on innovation in social services in Europe (sectors of Health, Education and Welfare Services). Report supported under the Socio-economic and Humanities Programme of FP7, European Commision.

Czarniawska, B. (2007). Shadowing And Other Technoques for Doing Fieldwork in Modern Societies. CBS Press.

Dewey, J., \& Bentley, A. F. (n.d.). Knowing and the Known.”. In J. A. Boydston (Ed.), John Dewey: the later works, 1925-1953 (Vol. 1952). Carbondale: Southern Illinois University Press.

Digmann, A., Nielsen, A. M., \& Ejlersen, L. S. (2018). "Dem der siger, at det ikke kan lade sig gøre, skal lade vær' med at afbryde os, der allerede er i gang”. Samfundslederskab i Skandinavien, 33(5), 369. https://doi.org/10.22439/sis.v33i5.5633

Elkjaer, B., \& Simpson, B. (2011). Pragmatism : A lived and living philosophy . What can it offer to contemporary organization theory? Research in the Sociology of Organizations, (Philosophy and Organization Theory), 55-84. https://doi.org/10.1108/s0733-558x(2011)0000032005

Hartley, J., Sørensen, E., Torfing, J., Torfi, J., Hartley, J., Sørensen, E., ... Torfi, J. (2013). Collaborative Innovation: A Viable Alternative to Market Competition and Organizational Entrepreneurship. Public Administration Review, 73(6), 821-830. https://doi.org/10.1111/puar.12136 
Hernes, T. (2017). En procesteori om organisation. Djøf Forlag.

Mead, G. H. (1932). The philosophy of the present. Illinois: La Salle.

Melander, P. (2018). Hvad er meningen? Samfundslederskab i Skandinavien, 33(2), 67. https://doi.org/10.22439/sis.v33i2.5541

Millard, J., \& Carpenter, G. (2014). Case study analysis report of online collaboration and networking tools for social innovation. A Deliverable of the Project:"The Theoretical, Empirical and Policy Foundations for Building Social Innovation in Europe"(TEPSIE), European Commission-7th Framework Programme. European Commission. DG Research, Brussels (2014b). Http://Www. Tepsie. Eu.

Moore, M. H. (1995). Creating public value: Strategic management in government. Harvard university press.

Murray, R., Caulier-grice, J., \& Mulgan, G. (2010). The Open Book of Social Innovation, 224. https://doi.org/10.1371/journal.pcbi.0030166

Nickelsen, N. C. M., \& Elkjaer, B. (2017). Shifting boundaries in telecare-the nurse-doctor relationship. Journal of Workplace Learning, 29.7(8), 588-600. https://doi.org/10.1108/jwl-03-2017-0024

Pink, S. (2009). Doing sensory ethnography. Thousand Oaks. Ca: Sage.

Sabato, S., Vanhercke, B., \& Verschraegen, G. (2017). Connecting entrepreneurship with policy experimentation? The EU framework for social innovation. Innovation: The European Journal of Social Science Research, 30(2), 147-167. https://doi.org/10.1080/13511610.2017.1282308

Simpson, B. (2009). Pragmatism, mead and the practice turn. Organization Studies, 30(12), 13291347. https://doi.org/10.1177/0170840609349861

Sørensen, E., \& Torfing, J. (2018). Den offentlige sektor som arena for samskabelse. In M. K. Fogsgaard \& M. de Jongh (Eds.), Ledelse og samskabelse i den offentlige sektor (pp. 30-61). Dansk Psykologisk forlag.

Tortzen, A. (2019). Samskabelse af velford. Muligheder og faldgruber. Copenhagen: Hans Reitzels Forlag.

Ulrich, J. (2018). Samskabelse - hvilke værdier kan der høstes? In Ledelse og samskabelse i den 
offentlige sektor (pp. 62-91). Dansk Psykologisk Forlag.

Weick, K. E. (2001). Making sense of the organization. Mass: Blackwell Business.

i http://www.fremtidsforskning.dk/?page_id=1792

ii www.mature-project.dk 